\title{
SILVER DOPING EFFECT ON ANTIBACTERIAL ACTIVITIES OF CADMIUM OXIDE NANOPARTICLES
}

\author{
J. Christina Rhoda ${ }^{1, *}$, M. Giruba ${ }^{1}$, S. Chellammal ${ }^{1}$, K. Ravichandran ${ }^{2}$ \\ and C. Sivaraj ${ }^{3}$ \\ ${ }^{1}$ Advanced Science Research and Development Centre, Department of Physics, \\ Dr. M.G.R. Educational and Research Institute, Chennai 600 095, (T.N), India \\ ${ }^{2}$ Department of Nuclear Physics, University of Madras (Guindy Campus), \\ Chennai 600 025, (T.N), India \\ ${ }^{3}$ Research Analyst, Armats Biotek Training and Research Institute, Guindy, \\ Chennai 600 032, (T.N), India \\ *E-mail: j.christinarhoda@yahoo.com
}

\begin{abstract}
Cadmium oxide nanoparticles were synthesized with cadmium chloride and sodium hydroxide as starting materials using the co-precipitation method. This study analyses the enhancement of antibacterial activities of cadmium oxide on the addition of silver. The antibacterial activity was carried out in-vitro against two kinds of bacteria: grampositive bacteria, Micrococcus Luteus and gram-negative bacteria, Escherichia Coli using the well diffusion method. The tested concentration range of cadmium oxide nanoparticles was $100 \mu \mathrm{m} / \mathrm{mL}, 150 \mu \mathrm{m} / \mathrm{mL}, 200 \mu \mathrm{m} / \mathrm{mL}$. The results showed that cadmium nanoparticles had an inhibitory effect against both pathogenic bacteria with a zone of inhibition $(18,20,24 \mathrm{~mm})$ for Micrococcus Luteus and $(14,16,18 \mathrm{~mm})$ for Escherichia Coli. The antibacterial effect was more prominent against the high concentration of nanoparticles. Cadmium oxide nanoparticles with silver as a dopant excel in different potential applications.
\end{abstract}

Keywords: Cadmium Oxide, Antibacterial Effects, Zone of Inhibition, Silver, Well Diffusion Method.

(C) RASĀYAN. All rights reserved

\section{INTRODUCTION}

Nanomaterials have gained the utmost importance due to their size-dependent properties. To improve the efficiency of the effects of antibacterial activity in various applications research has been conducted. However, due to the toxicity of certain materials, probing their application has been restricted. Inorganic materials with antibacterial effects provide high bacterial resistance and thermal stability. To eliminate the industrial bacteria these nanomaterials could be synthesized and used as an application. ${ }^{1}$ Nanomaterials could also be used as appropriate alternatives for traditional antibiotics since they are more resistant to pathogenic bacteria. Finding a prompt method to control the development of bacteria and its activity is much needed. Antibiotics with differing mechanism are necessary for alterations in the traditional treatments. $^{2}$

The synthesis and development of nanoparticles with enhanced antibacterial properties are needed since the emergence of new resistant bacterial strains to present-day antibiotics is a grave public health issue. ${ }^{3}$ Exploring the productivity of nanomaterials with antibacterial properties may give effective results in the disinfection of bacteria in the environment. Finding a rapid method to control the development of growth is of extreme importance. Nanomaterials display a robust inhibitory effect on a broad spectrum of bacterial strains. In recent years, studies were conducted in exploring the applications of cadmium oxide in optoelectronics, gas sensors, solar cells, transparent electrodes and photoelectrochemical cells. ${ }^{4-7}$ This study will highlight the enhancement of the antibacterial activity of cadmium oxide nanoparticles on the addition of silver against pathogenic agents, Micrococcus Luteus and Escherichia Coli.

Capping agents aid in achieving the stability and water solubility of nanoparticles thereby avoiding aggregation of materials during formation. ${ }^{8}$ The addition of capping agents is essential to enhance the

Rasayan J. Chem., 13(2), 915-919(2020)

http://dx.doi.org/10.31788/RJC.2020.1325619

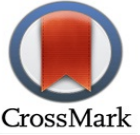


RASĀYAN J. Chem.

Vol. 13 | No. 2 |915 - 919| April - June | 2020

antibacterial activity of nanoparticles. It also improves the efficiency of nanoparticles and materials. ${ }^{9}$ Glycerol is used as the capping agent during the synthesis process.

\section{EXPERIMENTAL}

\section{Materials and Methods}

The materials used for the preparation of cadmium oxide and silver (Ag) doped cadmium oxide are cadmium chloride, silver nitrate, sodium hydroxide. All chemicals were of analytical reagent grade and were purchased from Loba Chemie Pvt. Ltd. and Fisher scientific. Double distilled water was used throughout the synthesis process. As-prepared $\mathrm{CdO}$ and $\mathrm{Ag}$-doped $\mathrm{CdO}$ were synthesized by the coprecipitation method at room temperature with glycerol as the capping agent. ${ }^{10,11}$ Capping agent plays an essential role in controlling the size of the nanoparticles during synthesis. ${ }^{12,13} \mathrm{~A} 1.0 \mathrm{M}$ of cadmium hydroxyl solution was prepared by dissolving cadmium chloride $\left(\mathrm{CdCl}_{2} \mathrm{H}_{2} \mathrm{O}\right)$ in deionized water under continuous stirring for 1 hour. Doping of silver was done by adding silver nitrate $\left(\mathrm{AgNO}_{3}\right)$ solution to the cadmium hydroxyl solution. Further, to maintain a particular $\mathrm{pH}$, sodium hydroxide was added dropwise to the resultant solution. The precipitated product was filtered, washed several times with deionized water and methanol and dried in an oven. ${ }^{14}$

\section{Microbial Strains and Nutrient Broth Medium}

Micrococcus Luteus, gram-positive bacteria and Escherichia Coli, gram-negative bacteria, were taken for the evaluation of antibacterial activity with tetracycline as the standard reference. An aseptic laminar chamber, which consists of a wooden box, was cleansed with $70 \%$ ethanol followed by irradiation of UV light from a lamp source. For the preparation of nutrient broth, peptone, yeast, sodium chloride, agar and distilled water were added in a particular proportion. This solution was suspended in distilled water of $200 \mathrm{~mL}$ kept in a $500 \mathrm{ml}$ conical flask which is then stirred, boiled to dissolve then autoclaved at a temperature of $121^{\circ} \mathrm{C}$ at $15 \mathrm{lbs}$ for a time limit of 15 minutes. In an aseptic laminar chamber, sterile Petri plates were placed and the hot medium was poured on it. Solidification of the medium was done for a time of 15 minutes.

\section{Agar Well Diffusion Method}

Cadmium oxide nanoparticles were screened for their antibacterial effect against pathogenic bacteria, Micrococcus Luteus and Escherichia Coli using well diffusion method. ${ }^{15,16}$ The bacterial cultures were subcultured in the nutrient broth medium. In a test tube containing inoculum, cotton swabs are immersed. These cotton swabs were spread evenly on the Petri plates containing the solidified agar medium. ${ }^{17}$ Sterile borer was used to make wells of a diameter of $8 \mathrm{~mm}$ in each plate. Cadmium oxide nanoparticles were then placed into each well having a concentration of 100,500 and $200 \mu \mathrm{g} / \mathrm{mL}$ using a micropipette. At a temperature of $37^{\circ} \mathrm{C}$, the plates were incubated for 24 hours. ${ }^{18}$ The zone of inhibition formed around the wells on each plate was taken into account for measuring the antibacterial activity. Tetracycline, a wellknown antibiotic was used as a positive control for standard reference.

\section{RESULTS AND DISCUSSION}

The nanoparticles were synthesized using the co-precipitation technique. The structural properties were studied using the X-ray diffraction technique and the patterns showed sharp and high-intensity diffraction peaks indicating that the sample is of good crystalline nature. Surface morphology and elemental composition analysis were investigated and the results were published. ${ }^{14,19}$ UV-Vis absorption spectroscopic analysis in diffuse reflectance mode and Fluorescence lifetime studies were also done and reported. ${ }^{19}$ Since capping agents enhances the antibacterial activity, glycerol was used as a capping agent during the synthesis process.

The antibacterial activity of cadmium oxide nanoparticles is shown in Fig.-1. Since the bacterial strain (Micrococcus Luteus) is susceptible to the antibacterial agent (cadmium oxide), a well- defined zone appears around the sample. This zone of inhibition appearing on the agar plate shows the level of inhibitory activity by the nanoparticles. Figure- 2 shows the comparison of inhibition zones caused by $\mathrm{CdO}$ and $\mathrm{CdO}: \mathrm{Ag}$ nanoparticles against the growth of Micrococcus Luteus and Escherichia Coli bacteria. 
RASĀYAN J. Chem.

Vol. 13 | No. 2 |915 - 919| April - June | 2020

Cadmium oxide microplates show prominent cell inhibition of $24 \mathrm{~mm}$ for Micrococcus Luteus and $18 \mathrm{~mm}$ for Escherichia Coli at $200 \mu \mathrm{g} / \mathrm{mL}$ concentration. Silver-doped Cadmium oxide nanoparticles showed a maximum zone of inhibition of $26 \mathrm{~mm}$ for Micrococcus Luteus. The most significant effect of the nanoparticle is found for the concentration of $200 \mu \mathrm{g} / \mathrm{mL}$ against Micrococcus Luteus. A Higher zone of inhibition is found with gram-positive bacteria compared to that of gram-negative bacteria. The applied concentration in each well has a direct association with the number of cells.

The antibacterial effect was more prominent at a higher degree of concentration of nanomaterials in studies done previously. ${ }^{20,21}$ In the present study, the antibacterial activity of $\mathrm{CdO}$ and $\mathrm{CdO}: \mathrm{Ag}$ is higher for the higher concentration of $200 \mu \mathrm{g} / \mathrm{mL}$. This is also seen in the studies done by Vinod et al. ${ }^{22}$

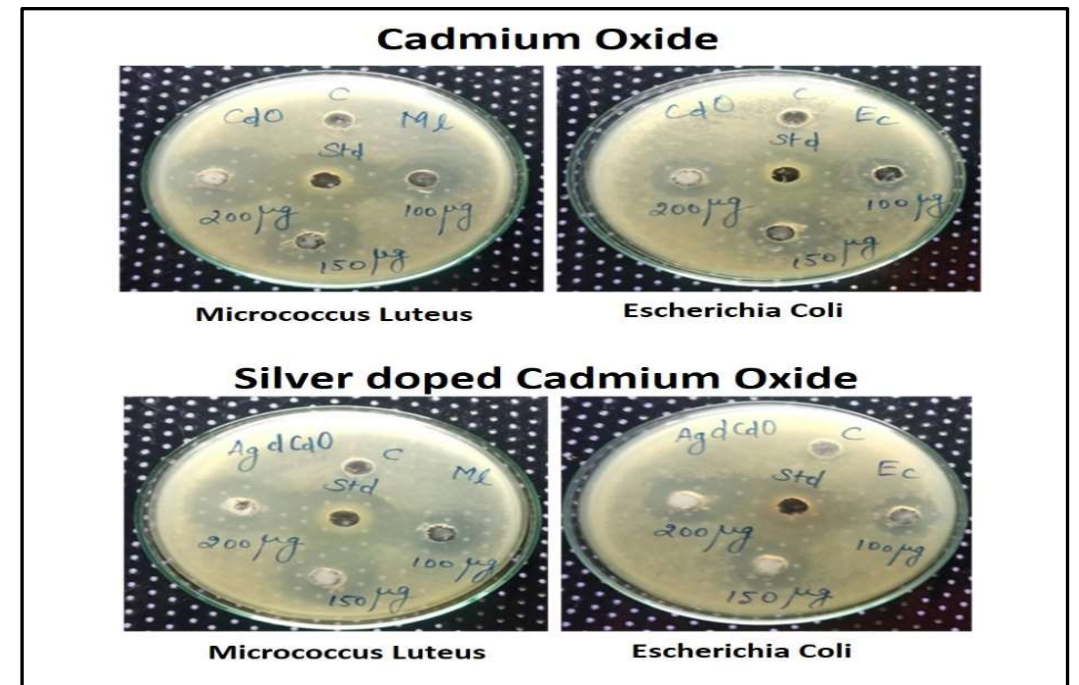

Fig.-1: Zone of Inhibition on Cadmium Oxide and Silver Doped Cadmium Oxide Nanoparticles

$\mathrm{CdO}$ nanoparticles show significant antibacterial activity due to the generation of reactive oxygen species and the release of $\mathrm{Cd}^{2+}$ ions. The bacterial cell wall experiences oxidative stress due to the reactive oxygen species formed on the surface of the nanoparticles. This stress eventually leads to the death of the bacterial cell. Reactive oxygen species contain hydroxyl radical $\left(\mathrm{OH}^{-}\right)$and superoxide anion radical $\left(\mathrm{O}_{2}{ }^{-}\right)$ which could damage the DNA and cell membrane. The nanoparticles get attached to the bacteria due to an electrostatic attraction between them. ${ }^{23}$ This contact inhibits the growth of bacteria and the formed ROS kills the cell. ${ }^{24}$ This inhibitory activity could also be explained due to the reaction between ions discharged from the nanoparticles and thiol groups of proteins present on the cell membrane of bacteria. These cellular proteins then allow the nutrients through the cell membrane. The difference in the antibacterial activity of $\mathrm{CdO}$ and $\mathrm{CdO}: \mathrm{Ag}$ nanoparticles were associated with cell capsular degradation.

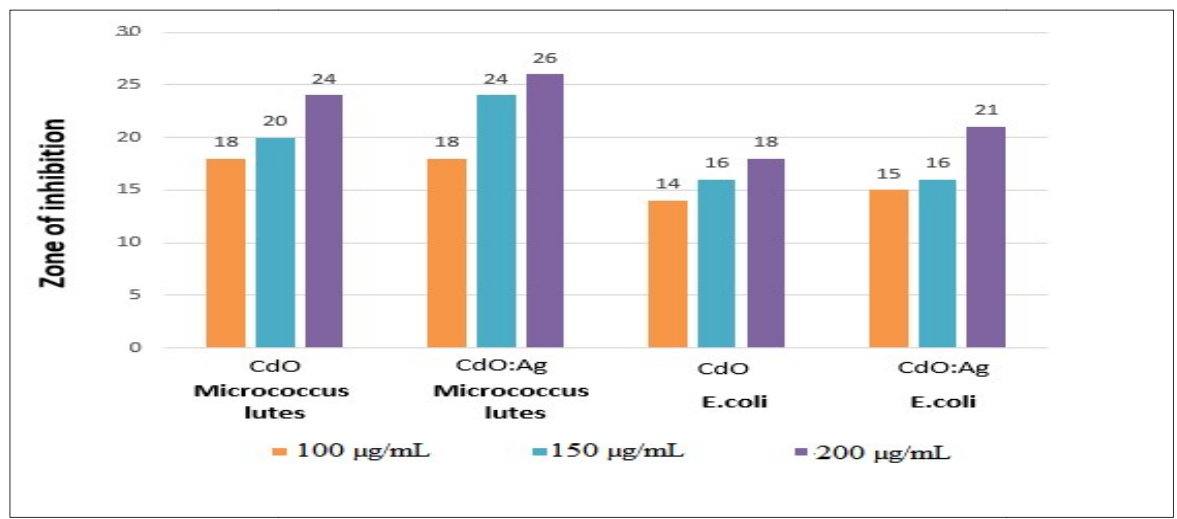

Fig.-2: Inhibition zones caused by $\mathrm{CdO}$ and $\mathrm{CdO}$ : Ag Nanoparticles against the Growth of Micrococcus Luteus and Escherichia Coli Bacteria

917 
RASĀYAN J. Chem.

Vol. 13 | No. 2 |915 - 919| April - June | 2020

Table-1: The Bactericidal Effects of Cadmium Oxide Nanocrystallites.

\begin{tabular}{c|c|c|c|c|c}
\hline Nanoparticle & Microbes & \multicolumn{3}{|c|}{ Zone of Inhibition $(\mathrm{mm})$} & \multirow{2}{*}{$\begin{array}{c}\text { Standard } \\
\text { (Tetracycline) }\end{array}$} \\
\cline { 3 - 5 } & & $\begin{array}{c}100 \\
\mu \mathrm{g} / \mathrm{mL}\end{array}$ & $\begin{array}{c}150 \\
\mu \mathrm{g} / \mathrm{mL}\end{array}$ & $\begin{array}{c}200 \\
\mu \mathrm{g} / \mathrm{mL}\end{array}$ & \\
\hline \multirow{2}{*}{$\mathrm{CdO}$} & Micrococcus Luteus & 18 & 20 & 24 & 22 \\
\cline { 2 - 5 } & Escherichia Coli & 14 & 16 & 18 & 21 \\
\hline \multirow{2}{*}{$\mathrm{CdO}: \mathrm{Ag}$} & Micrococcus Luteus & 18 & 24 & 26 & 24 \\
\cline { 2 - 5 } & Escherichia Coli & 15 & 16 & 21 & 22 \\
\hline
\end{tabular}

\section{CONCLUSION}

The results showed that the zone of inhibition increases on the addition of silver and it is higher for a higher concentration of nanoparticles. This shows the enhancement of antibacterial activity in cadmium oxide nanoparticles on the addition of silver as a dopant. The enhanced antibacterial efficiency observed makes silver doped cadmium oxide nanoparticles a suitable disinfectant for the elimination of industrial bacteria.

\section{ACKNOWLEDGMENT}

The corresponding author duly appreciates the fellowship, 'Founder Chancellor Fellowship Award' given by the Institute.

\section{REFERENCES}

1. B. Salehi, S. Mehrabian, M. Ahmadi, Journal of Nanobiotechnology, 12, 26(2014), DOI:10.1186/s12951-014-0026-8

2. T. K. Jana, S. K. Maji, A. Pal, R. P. Maiti, T. K. Dolai, K. Chatterjee, Journal of Colloid and Interface Science, 480, 9(2016), DOI:10.1016/j.jcis.2016.06.073

3. C. R. Lee, I. H. Cho, B. C. Jeong, S. H. Lee, International Journal of Environmental Research and Public Health, 10, 4274(2013), DOI:10.3390/ijerph10094274

4. A. Gopalakrishnan, R. Sha, N. Vishnu, R. Kumar, S. Badhulika, Nano-Structures and Nano-Objects 16, 96(2018), DOI:10.1016/j.nanoso.2018.05.004

5. J. B. Bult, R. Crisp, C. L. Perkins, J. L. Blackburn, ACS Nano 7, 7251(2013), DOI: $10.1021 / \mathrm{nn} 402673 \mathrm{z}$

6. S. Majumder, A. C. Mendhe, D. Kim, B.R. Sankapal, Journal of Alloys and Compounds, 788, 75(2019), DOI:10.1016/j.jallcom.2019.02.159

7. K. Sankarasubramanian, P. Soundarrajan,T. Logu, K. Sethuraman, K. Ramamurthi, New Journal of Chemistry, 42, 1457(2018), DOI:10.1039/c7nj03095a

8. S. Jaiswal, B. Duffy, A. K. Jaiswal, N. Stobie, P. McHale, International Journal of Antimicrobial Agents 36, 280(2010), DOI:10.1016/j.ijantimicag.2010.05.006

9. V. Vadlapudi, European Journal of Applied Sciences, 7, 297(2015), DOI:10.5829/idosi.ejas.2015.7.6.101202

10. A. S. Lanje, R. S. Ningthoujam, S. J. Sharma, R. B. Pode, Indian Journal of Pure and Applied Physics, 49, 234 (2011)

11. K. Mohanraj, D. Balasubramanian, J. Chandrasekaran, A. C. Bose, Materials Science in Semiconductor Processing, 79, 74(2018), DOI:10.1016/j.mssp.2018.02.006

12. C. M. Phan, H. M. Nguyen, Journal of Physical Chemistry A, 121, 3213(2017), DOI:10.1021/acs.jpca.7b02186

13. M. Masab, H. Muhammad, F. Shah, M. Yasir, M. Hanif, Materials Science in Semiconductor Processing, 81, 113(2018), DOI:10.1016/j.mssp.2018.03.023

14. J. C. Rhoda, M. Giruba, S. Chellammal, AIP Conference Proceedings, 2115, 030184(2019), DOI: $10.1063 / 1.5113023$

15. F. Nakhjiri, M. Mirhosseini, M. Alsadat Mozaheb, Rasayan Journal of Chemistry, 4, 98(2017), DOI:10.7324/RJC.2017.1041875

16. A. Raj, R. Lawerence, Rasayan Journal of Chemistry, 11, 1339(2018), DOI:10.31788/RJC.2018.1132009

17. I. M. Sudarma, M.G. Darmayanti, Sarkono, Rasayan Journal of Chemistry, 12, 761(2019), 
RASĀYAN J. Chem.

Vol. 13 | No. 2 |915 - 919| April - June | 2020

DOI:10.31788/RJC.2019.1225115

18. R. Sivanand, S. Chellammal, S. Manivannan, International Journal of Innovative Technology and Exploring Engineering, 9, 1324(2020), DOI:10.35940/ijitee.b6559.019320

19. J. C. Rhoda, M. Giruba, S. Chellammal, K. Ravichandran, K. Achyutha, Journal of Advanced Research in Dynamical \& Control Systems 11, 1396(2019).

20. D. Pathania, G. Sharma, A. Kumar, N. C. Kothiyal, Journal of Alloys and Compounds, 588, 675 (2014), DOI:10.1016/J.JALLCOM.2013.11.133

21. D. Pathania, G. Sharma, M. Naushad, A. Kumar, Journal of Industrial and Engineering Chemistry, 20, 3596(2014), DOI:10.1016/J.JIEC.2013.12.054

22. V. K. Gupta, D. Pathania, M. Asif, G. Sharma, Journal of Molecular Liquids 196, 107(2014), DOI:10.1016/j.molliq.2014.03.021

23. K. Karthik, S. Dhanuskodi, C. Gobinath, S. Sivaramakrishnan, Spectrochimica Acta Part A: Molecular and Biomolecular Spectroscopy, 139, (2014), DOI:10.1016/j.saa.2014.11.079.

24. C. Karthikeyan, V. Senthil kumar, S. Kumaresan, G. Ravi, Journal of Materials Chemistry B, 1, 5950(2013).

[RJC-5619/2019] 